\title{
Synthesis of TAK-733
}

Synthesis of Natural

Products and

Potential Drugs

\section{Key words}

\section{TAK-733}

MEK inhibitors

3-fluoropyridone

cascade reaction<smiles>COC(=O)C(F)C(=O)OC</smiles>

A

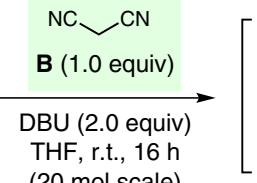

(20 mol scale)<smiles>COC(=O)C(F)C(O)=C(C#N)C#N</smiles>

\section{$40 \%$ aq $\mathrm{MeNH}_{2}$ (6.65 equiv), r.t., $2 \mathrm{~h}$ \\ then $\mathrm{NaOH}$ (1.5 equiv), r.t., $5 \mathrm{~h}$ \\ $80 \%$ from $\mathbf{A}$}<smiles>N#Cc1c(O)c(F)c(=O)n([O+]=[W][Na])c1N</smiles>

$\mathrm{POCl}_{3}$ (3.0 equiv)

$\mathrm{MeCN}, \Delta, 3 \mathrm{~h}$

$67 \%$ (16.4 mol scale)<smiles>Cn1c(=O)c(F)c(Cl)c2c(=O)n(C[C@H]3COC(C)(C)O3)cnc21</smiles>
H mp not reported

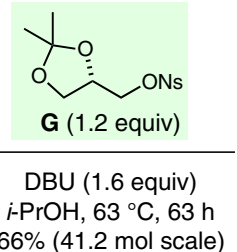

$66 \%(41.2 \mathrm{~mol}$ scale $)$<smiles>Nc1ccc(I)cc1I</smiles><smiles>Cn1c(=O)c(F)c(Cl)c2c(=O)[nH]cnc21</smiles>

$F$

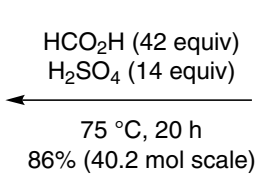

$75^{\circ} \mathrm{C}, 20 \mathrm{~h}$
$86 \%(40.2 \mathrm{~mol} \mathrm{scale})$

$\overbrace{\substack{\mathrm{N} \\ \mathrm{Me}}}^{\mathrm{H}_{2} \mathrm{~N}}$

E

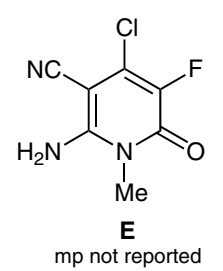<smiles>Cn1c(=O)c(F)c(Nc2ccc(I)cc2F)c2c(=O)n(C[C@H]3COC(C)(C)O3)cnc21</smiles>

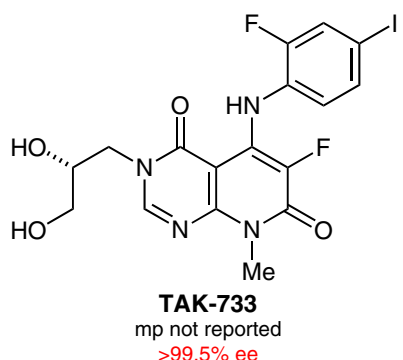

Significance: MEK kinases regulate the pathway that mediates proliferative and anti-apoptotic signaling factors that promote tumor growth and metastasis. TAK-733 is an MEK kinase inhibitor that entered phase I clinical trials for the treatment of cancer. A noteworthy feature of this short synthesis (25\% yield overall) is the one-pot, three-step synthesis of the fluoropyridone $\mathbf{D}$, in which the fluorine atom is present at the outset.
Comment: The reaction of $\mathbf{F}$ with the nosylate $\mathbf{G}$ gave a mixture of $\mathrm{N}$ - and $\mathrm{O}$-alkylation products (8:1) from which the desired $\mathrm{N}$-alkylation product was isolated by crystallization. The mixture of $\mathrm{N}$-methyl pyrrolidine (NMP) and methanol used in the final deprotection step, helped to ensure formation of the desired polymorph. The nine-step discovery synthesis (3\% overall yield) is also presented. 